\title{
Business Model Design: Lessons Learned from Tesla Motors
}

\author{
Yurong Chen ${ }^{1,2}, \&$ Yannick Perez ${ }^{1,3,4}$ \\ ${ }^{1}$ CentraleSupélec, 3 rue Joliot Curie, Plateau de Moulon, 91192 Gif-sur-Yvette cedex, France \\ ${ }^{2}$ Laboratoire Génie Industriel, Grande Voie des Vignes, F-92295 Châtenay-Malabry Cedex, France \\ ${ }^{3}$ Université Paris-Sud, RITM, 15, rue Georges Clemenceau, Orsay cedex, 91405, France \\ ${ }^{4}$ Armand Peugeot Chair (CentraleSupélec-ESSEC Business School)
}

\section{Abstracts}

Electric vehicle (EV) industry is still in the introduction stage in product life cycle, and its dominant design is still dormant. EV manufacturing companies have long taken numerous endeavors to promote $\mathrm{EV}$ in the niche markets by providing innovative business models. While most OEMs still take 'business as usual' approach for developing their EV production and offers, Tesla Motors, an EV entrepreneurial firm, stands out by providing disruptive innovation choices and solutions. The authors review the business model approach in literature, then classify the innovation dimensions in EV industry. We study on Tesla Motors accordingly: (i) innovation related to the vehicle, (ii) innovation related to the battery (iii) innovation concerning the infrastructure system and (iv) innovation toward value configuration. We extract four main lessons for classical OEMs: Tesla Motors 1) holds a product strategy entering from high-end market and moving to mass market, with a high level of innovation adaptation and learning by doing; 2) pays a considerable attention to reduce range anxiety by high performance supercharger station network and high capacity battery; 3 ) shows a high integration of information technology into many aspects of EV business model, such as advanced in-car services, and digital distribute channel; 4) shows a new value configuration which involve a massive use of vertical integration from EVs manufacturing towards battery software, recharging network and battery manufacturing. All these lessons would worth the attention of the OEMs if the Tesla disruptive choices succeed in challenging the dominant design.

Keywords: Dominant Design; EV industry; Business Model; Tesla Motor; disruptive innovation. 


\section{Introduction}

Business model innovation is one kind of disruptive innovations that will bring new effect on the market and bring challenges to the incumbent firm. It will enlarges the existing economic pie by attracting new customers or by encouraging existing customers to consume more (Markides, 2006). The study of business model innovation has become an important part in the emerging stage of a product or service in both literature and market (Amit \& Zott, 2001; Baden-Fuller \& Haefliger, 2013). As it has the potential to enable that technology advantages can be translated into a valuable market offering in times where the technology is still immature and, if proven successful, help gaining a competitive advantage in the long run.

The electric vehicles (EVs) have long been under emerging stage. It has a history of more than 100 years, with significant efforts in the early 20th century, followed by sequences of stops and starts and now new enthusiasm in the last decade. The new enthusiasm comes with high oil prices, climate protection policies, battery technology and recharging infrastructure development, and the rise of organized car sharing and intermodality (Dijk, Orsato, \& Kemp, 2013). EVs are believed to play an important part in the near future according to policy makers, car companies and other stakeholders. Ambitious regional and national goals have stimulated the progress of EV penetration by subsidizes for the vehicle and corresponding infrastructure deployment (Dijk et al., 2013; Lu, Rong, You, \& Shi, 2014). Meanwhile, most car manufacturers have added EVs in their portfolios and prepared to make mass production with different level of strategies and expectations. However, commercialization has been ineffective thus far, and dominant design is still dormant (Dijk et al., 2013). Sales of EV are far from satisfaction and lag behind from national goals. Accordingly, EV industry is still in the introduction stage in product life cycle, and struggling to take advantage of economies of scale in small niche markets. EV enterprises, including incumbent and entrepreneurial OEMs, have long taken numerous endeavors to promote EV in the niche markets by providing innovative business models, to promote EVs and overcome technological shortcomings overcome (eg. range anxiety).

Tesla Motor, viewed as a black horse to the auto industry, is an entrepreneurial firm dedicated for Electric vehicle scenario. Founded in 2003, Tesla Motor obtains a success as an OEM dedicated for EV, and changed people's idea of EV as well as re-initiated the enthusiasm for pure EVs. The international sales of Tesla model $\mathrm{S}$ ranked $4^{\text {th }}$ and $3^{\text {rd }}$ for year 2013 and 2014 respectively in all categories of EV (eg. BEV, PHEV, HEV, FCEV). 
Comparing to incumbent firm, entrepreneurial firms are generally less constrained in the evaluation of alternative models and more flexible in pursuing radical business models (Bohnsack, Pinkse, \& Kolk, 2014). While most OEMs still take 'business as usual' approach for developing their EV production and offers, Tesla Motors stands out by providing disruptive innovation solutions (Markides, 2006). As a result, we are concerned about the business model design of tesla and would like to draw several lessons for more classical OEMs in their business model design of EV.

This paper starts with reviewing the business model approach in literature, then classify the innovation dimensions in EV industry is addressed. By combine those two elements, a business model innovation frame for EV is developed in section II. Section III is dedicated to review and analysis the business model of Tesla Motor. Section IV follows up with the conclusion and lessons addressed for more classical OEMs

\section{Business model innovation frame for $\mathrm{EV}$}

\section{A. Business model approach}

The term "business model" is relatively new and keeps active ever since the business environment change shaped by new communication and computer technology (Osterwalder, 2004). The term became a buzzword and was used by managers, academics and journalists, however, solid grounding in economic or management and a uniformed no uniform definition or taxonomy is still missing (Günzel \& Holm, 2013; Osterwalder, 2004). Despite of the diversity of current contributions and understandings, researchers do agree that a business model describes how the enterprise creates and delivers value to customers, and then converts payments received into profits. In another word, it refers to what the company offers, to whom it offers it and how it can accomplish it (Osterwalder, 2004; D. J. Teece, 2010).

An accepted business model approach in research and practice involve a fundamental reconsideration of the value proposition (product/services), the customer interface (channel, relationship and customer segment), infrastructure management (capability, partnership and value configuration) and the financial aspects (revenue model, profit and cost) (Osterwalder \& Pigneur, 2002). In these elements, value proposition, customer interface and revenue model from financial aspects emphasizes on the value creating and value capture, while infrastructure management and other elements of financial aspects are predominantly efficiency driven elements (Günzel \& Holm, 2013). 
As EVs are in the emerging stage and paradigmatic design is still dormant, the elements on value creation and value capture design will have more influence in deciding the success of an disruptive technology (D. Teece, 1986). In order to explore the difference on the efficiency of firm organization, discussion on value configuration is also included in this study. In this way, we narrowed our study of business model into the five following elements: the value proposition $^{1}$, the consumer segment ${ }^{2}$, the distribution channel ${ }^{3}$, the revenue model $^{4}$ and finally the value configuration ${ }^{5}$.

\section{B. Classification of EV business model innovations}

In order to study the value configuration of Tesla Motor, we need to define the EV value chain first. The transition into an electric mobility trajectory will lead to fundamental changes in the value chain of the automobile which basically involving components from supplier, core components and assembling from OEMs, the energy utilities.

First of all, some modules such as internal combustion engine (ICE) will become less important in the long-term (Huth, Wittek, \& Spengler, 2013). While modules such as battery, charging infrastructure will enter the value chain and act as critical roles as a result of high cost and changing peoples' driving behavior (Kley et al., 2011; Weiller \& Neely, 2014). Secondly, new services enabled by EVs such as energy services or those enlarged by EVs such as car-sharing services and connective services will have numerous influences in the auto value chain (Fournier, 2012). At the moment, customer facing services such as energy services and mobility services still wait for EV penetration and changes in electricity grid regulation and people's behavior (Codani et al., 2014; Weiller \& Neely, 2014). As a result, the current EV value chain is emphasizing on battery (battery cell manufacturing and battery packing), vehicle (EV design, assembling and sales), and infrastructure enabling grid connection (infrastructure manufacturing and infrastructure network deployment) as it is showed in Figure 1.

\footnotetext{
${ }^{1}$ It defines the promised value of the firm's bundles products or services as well as complementary valueadded services, are packaged and offered by the manufacturer to fulfill customer needs beforehand (Kley, Lerch, \& Dallinger, 2011; Osterwalder, 2004)

${ }^{2}$ It defines the type of customers a company wants to address.

${ }^{3}$ It defines how a company delivers the product and services to target customers. It includes direct channel such as through a sales force or over a website, and indirect channel such as reseller and dealer network.

${ }^{4}$ It defines what type of payment the customer makes to the supplying shareholder in order to get the product or services.

${ }^{5}$ It defines the potential possibilities to design the product offered with regard to the different shareholders involved in a business model, it has three kind of configuration which are value chain, value shop and value network (Osterwalder, 2004). According to the characters of automobile industry, the value configuration is achieved by value chain.
} 


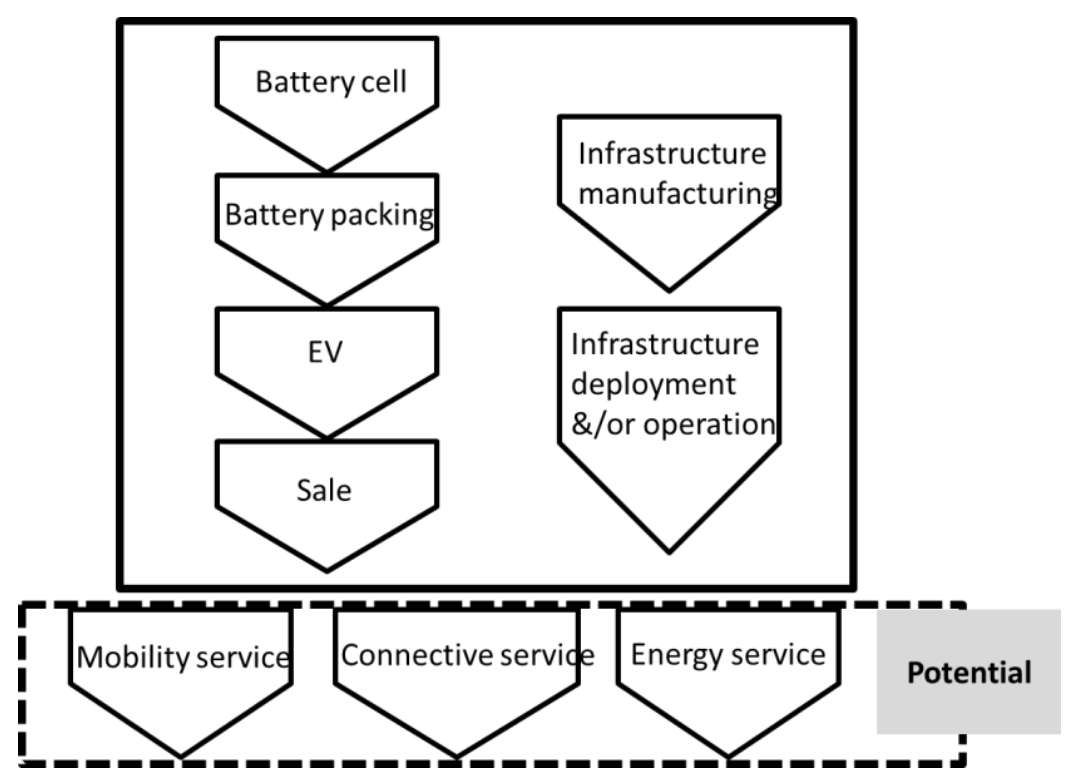

Figure Idefinition of EV value chain (adapted from (Fournier, 2012; Weiller \& Neely, 2014))

Furthermore, the EV industry involves new modules and components as a result of battery-based electric mobility concepts such as recharging infrastructure and related services. It is necessary to identify the different dimensions of the product and service from an EV firm in order to analysis its business model design. Three dimensions have been classified in a holistic study of EV, which are the vehicle together with battery; the infrastructure system; the system services which integrate electric vehicles into the energy system (Kley et al., 2011). At the moment, energy system service such as vehicle to grid services (V2G) still wait for EV penetration and changes in electricity grid regulation and people's behavior (Codani, Petit, \& Perez, 2014; Weiller \& Neely, 2014). In this way, we adapted the key dimensions of EV business model innovation into the following:

(i) The innovation towards the vehicle;

(ii) The innovation towards the battery;

(iii) The innovation towards the infrastructure system;

In the next section, we will analysis these three dimensions of business model innovation respectively according to the five value related elements of the business model. Furthermore, innovation towards value configuration will be analyzed to explain the firm organization innovation of Tesla Motor according to the three dimensions of EV. 


\section{Characterization of Tesla Motor Business}

\section{Model}

To meet the objective of this research, which is to analysis the business model design of Tesla Motor, we gather information mainly on the official website of Tesla Motor, as well as industry website EVobesession and ElectricCarsReport. We will perform the characterization of the Tesla business model by analyzing a) the innovation towards the vehicle; b) the innovation towards the battery; c) the innovation towards the infrastructure system and finally we will define its original d) value configuration.

\section{A. Innovation towards the vehicle}

Tesla motor has thus far released two vehicle models into market: a two doors sport car Tesla Roadster and a sedan Tesla Model S. Two other prototypes are waiting for commercialization: an SUV Tesla model $\mathrm{X}$ and a family car Tesla 3. Tesla gained high reputation for its high performance of the vehicle, which is corresponding to its high-end customer segment; and its innovative multi-channel for distribution.

\section{Value proposition}

- Vehicle performance

The Tesla Roadster, which is released in 2008, changed people's imagination on EV by offering a fancy looking sport car with offering a $0-100 \mathrm{~km} / \mathrm{h}$ within $3.7 \mathrm{~s}$ acceleration and a standard range of $393 \mathrm{~km}$ for one time charge.

Following by this, Tesla motor released Tesla model S in 2012, with purpose design for a premium family car. It has several different sub-type with acceleration performance varies from $3.2 \mathrm{~s}$ to $5.9 \mathrm{~s}$ for $0-100 \mathrm{~km} / \mathrm{h}$ acceleration, and the standard range varies from $335 \mathrm{~km}$ to $426 \mathrm{~km}$ for one time charge.

- Connective services with vehicle:

Besides the fancy appearance and strong vehicle performance, Tesla innovatively increased the connectivity between users and the environment ( eg. recharging station navigation, charging control and autopilot) enabled by IT based hardware and software applications. It innovatively offers data network in the car with telecommunication partners, and connect the car with maintenance centre, infotainment centre and so on. 


\section{Customer segment}

Tesla Motor entered the market by targeting on the high-end niche market, by offering luxury specific purpose vehicle Roadster. Model S target on luxury multi-purpose car market as a result the selling number is magnificently larger than the Roadster. Furthermore, according to the planning map of Tesla Motor, it will continue to offer an SUV version luxury multi-purpose car, followed by a more economically multi-purpose car. It is corresponding to the strategy goal to create an affordable mass market EV. The customer segments of battery and recharging system need to match the customer segment of vehicle.

The customer segment is largely different than other OEMs which usually enter from economy multi-purpose or economy specific-purpose market as the ownership cost for EV is high (Bohnsack et al., 2014).

\section{Distribution channel}

As a new comer to auto industry, Tesla Motor did not use the conventional dealership network for vehicle distribution. In contrast, it created a new multi-channel model for purchasing vehicles, which involved online stores and apple-like retail outlets. The online stores offer potential customer the chance to purchase the car directly online. Furthermore, the retail outlets are usually located in high traffic space, enhanced with technology with high integration of IT in order to better present Tesla vehicle and its company culture. Tesla applies a vertical integration on selling, which means the price of vehicle is non-negotiable. This caused some disputes in the conventional dealership network.

\section{Revenue model}

Tesla applied an ownership-as-usual model for revenue. Customers purchase the EV in order to possess the full ownership of the car including expensive batteries.

\section{B. Innovation towards the battery}

Battery is a critical module in electric vehicle since it carries high cost and value. The choice of battery will largely define the range anxiety that customers will face. Tesla applied an ambitious plan on the battery strategy, with expecting movements on battery factory and enters also the stationary battery market. It draws a lot of attention for its high range, and innovative battery pack technology.

\section{Value proposition}

\section{- Performance}


Both Tesla Roadster and Model S show a large capability for the range due to the high energy stored in battery. Tesla Model S equipped with very large 70 or $85 \mathrm{kWh}$ battery. This pack is able to run for $335 \mathrm{~km}$ under standard condition, while most other OEMs choose a 16-24 kWh battery pack allowing a small range from $100 \mathrm{~km}$ to $160 \mathrm{~km}$.

Tesla motor has a good knowledge on battery pack and management system. It innovatively equipped Tesla Roaster with thousands of laptop Lithium-ion cells and assembles them into a performance and cost optimized battery pack. During the delivery of Tesla Model S, it developed a closer relationship with its battery cell supplier Panasonic, on both battery technology and scale of production.

- Connectivity

As it is enabled by the connective service inside vehicle, Tesla user can have some control on battery system. For example, user can control the temperature of battery system before enter the car when the environment temperature is too low.

\section{Distribution channel \& Revenue model}

The battery is generally sold to customers along with the vehicle ${ }^{6}$, with possibility for extra purchase when the old one is at the end of life and need to be replaced.

\section{Innovation towards infrastructure system}

Another ambitious plan of Tesla Motor is the expansion of supercharger network. Until May 2015, there were 2,400 superchargers in 400 stations worldwide. It is famous for its high performance in charging ability, well established network and free to Tesla user strategy.

Value proposition:

- Performance

In align to the large capacity of battery adapted by Tesla, the supercharger station offers fast charging in order to satisfy the charging need for customers. It can deliver direct current up to $120 \mathrm{~kW}$ and capable of charging to $80 \%$ of an $85 \mathrm{kWh}$ Tesla Model S within 40min.

\footnotetext{
${ }^{6}$ Some options concerning the battery pack size are also possible. 3 versions are to be selected, $70 \mathrm{kWh}, 85$ $\mathrm{kWh}$ regular and $85 \mathrm{kWh}$ sport set.
} 
Beside the premium function of supercharger station, Tesla is enduring an ambitious expansion plan to establish superchargers network along well-traveled highways and in congested city centers.

As a substitute to charging station, a pilot battery swap program is also launch in California to meet the charging need for customer and reduce range anxiety. ${ }^{7}$

- Connectivity

As it is enabled by the connective service inside vehicle, Tesla user can find the nearest supercharging station and control the charging when connected.

\section{Distribution channel}

The public network is solely deployed by Tesla Motor Company. This is mainly due to the different charging technology and standard adapted by the companies, and the different cable designed and adapted. But in order to foster the adoption of these in-house technologies, Tesla allow the use of the patent for free if other OEMs want to use its new high performance charging system. In a nutshell, Tesla goes open source ${ }^{8}$.

\section{Revenue model}

Tesla users will benefit from free entrance to the supercharger stations network. However, Tesla Company needs to carry all the cost including installment, maintenance and network reinforcement if needed. The rent for the place is shared by supercharger partner program with local partners.

A summary of the innovation towards vehicle, battery, and infrastructure system is shown in Table 1.

\begin{tabular}{|c|c|c|c|}
\hline & $\begin{array}{c}\text { Innovation towards } \\
\text { vehicle }\end{array}$ & $\begin{array}{c}\text { Innovation towards } \\
\text { battery }\end{array}$ & $\begin{array}{l}\text { Innovation towards } \\
\text { infrastructure system }\end{array}$ \\
\hline $\begin{array}{l}\text { Value } \\
\text { proposition }\end{array}$ & $\begin{array}{lr}\text { High } & \text { performance } \\
\text { regarding to range and } \\
\text { vehicle performance; } \\
\text { innovative } \\
\text { services and intelligent } \\
\text { services }\end{array}$ & $\begin{array}{l}\text { Innovative } \\
\text { management of } \\
\text { battery packs enables } \\
\text { high capacity and low } \\
\text { cost; r connective } \\
\text { service enable interact } \\
\text { with user; new } \\
\text { product r towards } \\
\text { stationary rattery } \\
\text { market }\end{array}$ & \begin{tabular}{lr} 
High & performance \\
recharging & station with \\
highly & developed \\
recharging & station \\
network; & connective \\
service enable interact \\
\multicolumn{2}{l}{ with user; }
\end{tabular} \\
\hline Customer & Innovatively starting with & Corresponding to the & Corresponding to the \\
\hline
\end{tabular}

\footnotetext{
${ }^{7}$ http://www.teslamotors.com/blog/battery-swap-pilot-program
}

${ }^{8} \mathrm{http}: / /$ www.teslamotors.com/blog/all-our-patent-are-belong-you 


\begin{tabular}{|l|l|l|l||}
\hline segments & $\begin{array}{l}\text { high-end market; and } \\
\text { moving to mass market }\end{array}$ & vehicle & vehicle \\
\hline $\begin{array}{l}\text { Distribution } \\
\text { channel }\end{array}$ & $\begin{array}{l}\text { Innovative multi-channel } \\
\text { model, involving high } \\
\text { integration of IT; } \\
\begin{array}{l}\text { Vertical Integration on } \\
\text { selling }\end{array}\end{array}$ & $\begin{array}{l}\text { Together with vehicle, } \\
\text { replace possible }\end{array}$ & $\begin{array}{l}\text { Public } \\
\text { deployed by Tesla } \\
\text { Motor only }\end{array}$ \\
\hline $\begin{array}{l}\text { Revenue } \\
\text { model }\end{array}$ & Ownership-as-usually; & $\begin{array}{l}\text { purchase with vehicle } \\
\text { or separate purchase } \\
\text { when update }\end{array}$ & Free to Tesla user \\
\hline
\end{tabular}

Table 1 Business model of Tesla Motor from value-related perspective

\section{Innovation towards value configuration}

Tesla Motor shows a very original value configuration compare to other OEMs. During the delivery time of the Tesla Roadster, most components as well as battery cell manufacturing and vehicle design are outsourcing to the suppliers mainly due to the initial stage of the company and immaturity of the EV market; however, the packing and assembling of the battery cells and the energy management are conducted by Tesla. When the commercial delivery of Tesla Model S began, Tesla motor began to show a high level of vertical integration along its value chain. According to the value proposition of Tesla motor, it shows an integrated value configuration from battery packing, EV design, retail distribution to an intensively emphasized supercharger network (Figure 2-b). In the near future Tesla also want to integrate the battery cell manufacturing in its forthcoming Nevada Giga factory ${ }^{9}$. The Giga factory will produce cells for Tesla motors and Tesla Powerwall (Energy Storage for a Sustainable Home) battery pack for PV optimisation ${ }^{10}$.

In contrast in the conventional auto industry, the value chain consist the pyramid relationship between supplier and OEM relationship which supplier provides the fringe modules to OEMs such as gearbox and auxilliary battery and OEM produces the core conponent such as motor design and assembe the vehicle; on the other hand, energy utility will fill the car with fuel during the car lifetime as its showed in Figure 2-a. A classic OEM in-house production share is around 25\% in 2015 for total vehicle (Huth et al., 2013).

\footnotetext{
${ }^{9} \mathrm{http} / / /$ www.washingtonpost.com/business/capitalbusiness/the-gamble-on-teslas-gigafactory-is-a-big-one--inmany-fashions/2015/04/10/50e9de40-d4c8-11e4-a62f-ee745911a4ff_story.html

${ }^{10} \mathrm{http} / / /$ www.teslamotors.com/powerwall
} 

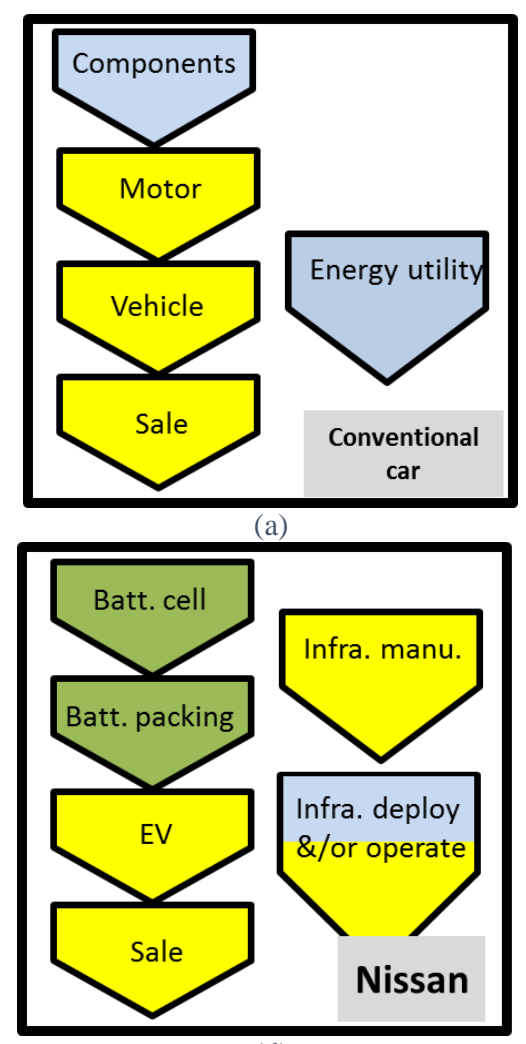

(d)
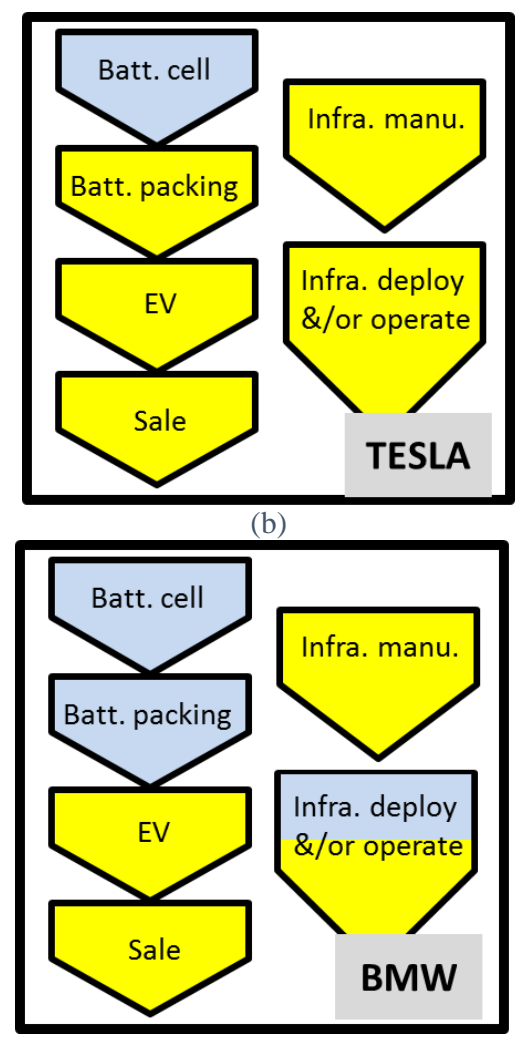

(e)
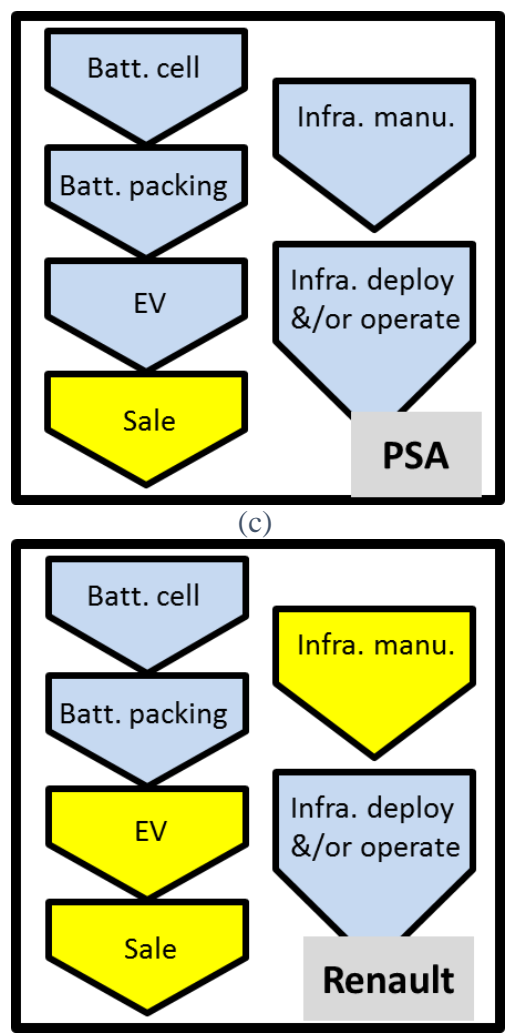

(f)

Figure 2 Value configurations of Tesla Motor and other OEMs (blue-outsource from supplier/ other utility; greenjoint venture; yellow-Vertical integration by OEM)

In EV industry, most OEMs who are greatly engaging in the EV market choose to follow their old routine of value configuration, which refers to integration-as-usual. In this type of value chain, OEMs treat battery as a module for outsource as before, it could be because of the limitation on technology knowledge or transaction cost concern. BMW I and Renault are examples as showed in Figure 2-e, f respectively. A more involved choice could be the OEM and battery supplier form an joint venture company, as it is the case for Nissan (Figure 2-d). On the other hand, as for the recharging network deployment, most OEMs wait for the action from recharging operation company or other stakeholder such as national or local government. Renault, BMW and Nissan followed this strategy, and their EVs are able to access to the recharging network deployment by chargepoint and chargemaster in USA and UK. Furthermore, BMW and Nissan started to invest in the recharging infrastructure network with partners from 2015 (Figure 2-d,e,f).

Companies which are less engaged in the EV market yet wish to keep EV in their product portfolio could choose to be less integrated in their value chain, and purchase the EV from another OEM. PSA is an example of this type of value configuration, it purchases the iMiEVs from Mitsubishi, and resale it in europe as Citroën C-Zero and Peugeot iOn battery. As a result, PSA only occupy the sale position in the value chain of EV(Figure 2-c ). 


\section{Conclusion}

This paper discusses the business model innovation of Tesla Motor regarding vehicle, battery, infrastructure system and its value configuration. Based on our findings, several lessons can be draw and would worth the attention of the more classical OEMs, if the Tesla Motor disruptive choices succeed in challenging the dominant design.

Top-down and flexible product strategy

Tesla Motors holds a product strategy entering from high-end market and moving to mass-market customer segment. It started with offering performance sport EV which ignited the market enthusiasm, following by providing the premium family EV and aiming to create affordable mass market for EV. At the same time, as an entrepreneurial firms, it with a high level of innovation adaptation and flexibility in learning by doing. More classical OEMs should also be more flexibility in pursuing radical business models, especially when the dominate technology and business modal design of EV are dormant.

Huge endeavor on range anxiety reduction

Tesla Motor holds ambitious plan to solve the range anxiety problem along with EV. It pays a considerable attention to both large capacity battery pack and high performance supercharger station. One of the most important long term strategy of Tesla Motor is the high performance supercharger station and its aggressive expansion around the main intercity highways in US and Europe. Furthermore, the strategy choice of battery range is much higher than the choice from other OEMs. All these aspects contribute to reduce the range anxiety of Tesla users and enable the high performance in the value proposition of business model. As range anxiety comes with the attributes of $\mathrm{EV}$ and become the most critical concern for customer, OEMs should also take certain actions to reduce the range anxiety with certain cost.

Integration of information technology

Tesla shows a very high level of integration of information technology into many aspects of EV business model. Tesla innovatively increased the connectivity between users and the environment such as charging station and battery. Furthermore, a high share of information technology is involved in both online and retail outlet distribution channels for Tesla. Nowadays, the connective service are with growing interest for both customer and 
OEMs, and it will increase the add-on-value of vehicle or after sell services, OEMs should take action on integrating information technology for both vehicle value proposition and distribution channel.

New value configuration with more integration

Tesla Motor holds a new value configuration which involving in high level of vertical integration towards battery and recharging network. The integration strategy will reduce coordinate cost between OEM and its supplier, and reduce risk caused by lack of supporting infrastructure, however, it also involves high investment and risk coming from the uncertainty of EV industry. EV is a relatively new industry in its emerging stage, OEMs need to value the trade-off and the transaction cost for the value configuration and firm organization they are possessing.

\section{Acknowledgements}

Yurong Chen benefits from the support of the Chair "PSA Peugeot Citroen Automobile: Hybrid technologies and Economy of Electromobility", so-called Armand Peugeot Chair led by CentraleSupélec, and ESSEC Business School and sponsored by PEUGEOT CITROEN Automobile. She would like to express her gratitude towards all partner institutions within the program as well as the Armand Peugeot Chair.

\section{References}

Amit, R., \& Zott, C. (2001). Value creation in e-business. Strategic Management Journal, 22(6-7), 493-520. http://doi.org/10.1002/smj.187

Baden-Fuller, C., \& Haefliger, S. (2013). Business Models and Technological Innovation. Long Range Planning, 46(6), 419-426. http://doi.org/10.1016/j.lrp.2013.08.023

Bohnsack, R., Pinkse, J., \& Kolk, A. (2014). Business models for sustainable technologies: Exploring business model evolution in the case of electric vehicles. Research Policy, 43(2), 284-300. http://doi.org/10.1016/j.respol.2013.10.014

Codani, P., Petit, M., \& Perez, Y. (2014). Missing money for EVs : economics impacts of TSO market designs. In Montpellier Energy Conference (MEC).

Dijk, M., Orsato, R. J., \& Kemp, R. (2013). The emergence of an electric mobility trajectory. Energy Policy, 52, 135-145. http://doi.org/10.1016/j.enpol.2012.04.024 
Fournier, G. E. A. (2012). The new mobility paradigm. Transformation of value chain and business models. Proceedings of the 20th Gerpisa International Colloquium 2012, (2011), 9-40.

Günzel, F., \& Holm, A. B. (2013). One Size Does Not Fit All -- Understanding the Front-End and Back-End of Business Model Innovation. International Journal of Innovation Management, 17(1), 1340002-1340034. http://doi.org/10.1142/S1363919613400021

Huth, C., Wittek, K., \& Spengler, T. S. (2013). OEM strategies for vertical integration in the battery value chain. International Journal of Automotive Technology and Management, 13(1), 75. http://doi.org/10.1504/IJATM.2013.052780

Kley, F., Lerch, C., \& Dallinger, D. (2011). New business models for electric cars-A holistic approach. Energy Policy, 39(6), 3392-3403. http://doi.org/10.1016/j.enpol.2011.03.036

Lu, C., Rong, K., You, J., \& Shi, Y. (2014). Business ecosystem and stakeholders' role transformation: Evidence from Chinese emerging electric vehicle industry. Expert Systems with Applications, 41(10), 4579-4595. http://doi.org/10.1016/j.eswa.2014.01.026

Markides, C. (2006). Disruptive innovation: In need of better theory. Journal of Product Innovation Management, 23, 19-25. http://doi.org/10.1111/j.1540-5885.2005.00177.x

Osterwalder, A. (2004). The Business Model Ontology. A proposition in a Design Science Approach. HEC Lausanne.

Osterwalder, A., \& Pigneur, Y. (2002). An eBusiness Model Ontology for Modeling eBusiness.

Teece, D. (1986). Profiting from technological innovation: Implications for integration, collaboration, licensing and public policy. Research Policy, 22(2), 112-113. http://doi.org/10.1016/0048-7333(93)90063-N

Teece, D. J. (2010). Business models, business strategy and innovation. Long Range Planning, 43(2-3), 172-194. http://doi.org/10.1016/j.lrp.2009.07.003

Weiller, C., \& Neely, a. (2014). Using electric vehicles for energy services: Industry perspectives. Energy, 77, 194-200. http://doi.org/10.1016/j.energy.2014.06.066 